\title{
FAKTOR PENDORONG KEBERLANJUTAN PENGELOLAAN SAMPAH RUMAH TANGGA BERBASIS PARTISIPASI MASYARAKAT DI KOTA BALIKPAPAN DAN BOGOR
}

\author{
Nino Heri Setyoadi \\ Balai Litbang Penerapan Teknologi Permukiman \\ Puslitbang Kebijakan dan Penerapan Teknlogi Balitbang PUPR \\ E-mail: ninososekkim@hotmail.com
}

\begin{abstract}
Abstrak
Upaya pengurangan dan penanganan sampah membutuhkan partisipasi penuh dari masyarakat. Upaya atau gerakan reduce, reuse, dan recycle (3R) juga belum menunjukkan hasil yang signifikan, terbukti hanya 7,5\% sampah yang diolah menjadi kompos dan daur ulang. Oleh karena itu, dibutuhkan suatu pengkajian mengenai faktor pendorong keberlanjutan pengelolaan sampah rumah tangga berbasis masyarakat. Tulisan ini bertujuan untuk menganalisis faktor-faktor pendorong keberlanjutan pengelolaan sampah partisipatif di kota Bogor dan Balikpapan. Pendekatan yang digunakan berupa metode kualitatif dengan menganalisis data melalui proses deskripsi, tendensi, dan interpretasi pada setiap faktor pendorong keberlanjutan pengelolaan sampah. Hasil penelitian ini menunjukkan terdapat 6 (enam) faktor pendorong yang berperan dalam keberlanjutan pengelolaan sampah di kota Bogor dan Balikpapan. Faktor pendorong tersebut meliputi peran tokoh masyarakat, manfaat ekonomi, manfaat sosial, manfaat lingkungan, jaringan pengelolaan sampah, serta stimulasi dan fasilitasi pemerintah daerah. Dari keenam faktor pendorong tersebut, peran tokoh masyarakat dan jaringan pengelolaan sampah merupakan faktor pendorong yang paling signifikan dalam mendorong keberlanjutan pengelolaan sampah berbasis partisipasi masyarakat.
\end{abstract}

Kata kunci : keberlanjutan, partisipasi masyarakat, faktor pendorong, sampah rumah tangga

\begin{abstract}
Solid waste reduction and handling efforts require full community participation. The 3R movement has not shown significant result, it was only $7.5 \%$ of waste that is processed into compost and recycle, $10 \%$ still in the grave in the ground, $5 \%$ was burned, and $8.5 \%$ unmanaged. As much as $69 \%$ of the total waste was dumped into the waste landfill. For that we need an assessment the push factors of sustainability of community-based solid waste management. This paper aims to analyze the push factors of sustainability community-based solid waste management in the cities of Bogor and Balikpapan. The approach used in the form of qualitative research methods through the process of description, tendency, and interpretation. The results showed that there are 6 (six) push factors that play a major role in the sustainability of community-based solid waste management in the cities of Bogor and Balikpapan. The push factors include the role of community leaders, economic benefits, social benefits, environmental benefits, the management network, and the stimulation and facilitation of local government. The role of community leaders and the waste management network was the most significant push factor in encouraging the sustainability of waste management based on community participation.
\end{abstract}

Keywords: community participation, push factor, domestic waste, and sustainability

Dikirim/submitted: 10 November 2017

Diterima/accepted: 28 Desember 2017 


\section{PENDAHULUAN}

Berdasarkan UU No. 18 Tahun 2008 tentang Pengelolaan Sampah, tujuan utama pengelolaan sampah adalah meningkatkan kesehatan masyarakat dan kualitas lingkungan serta menjadikan sampah sebagai sumber daya. Upaya pengelolaan sampah tersebut terdiri dari pengurangan sampah dan penanganan sampah. Pengurangan sampah dapat meliputi pembatasan timbulan, daur ulang, dan pemanfaatan kembali sampah, sedangkan penanganan sampah dapat meliputi upaya pemilahan, pengumpulan, pengangkutan, pengolahan dan pemrosesan akhir sampah (Direktorat PPLP, 2012).

Upaya pengurangan dan penanganan sampah membutuhkan partisipasi penuh dari masyarakat. Partisipasi masyarakat sangat penting karena masyarakat sebagai produsen sampah, masyarakat paling mengetahui kondisi pengelolaan sampah di lingkungannya. Selain itu masyarakatlah yang paling merasakan dampaknya jika sampah tidak terkelola dengan baik. Pengurangan sampah sejak dari sumbernya, khususnya sampah rumah tangga dan sejenisnya, tidak dapat berjalan tanpa keterlibatan keluarga dengan anggotanya. Demikian halnya dengan upaya penanganan sampah, kontribusi masyarakat berupa lahan, retribusi/iuran, kelembagaan komunitas dan dukungan lainnya sangat berpengaruh terhadap keberlanjutan penanganan sampah. Partisipasi aktif dari berbagai pihak seperti masyarakat dan pemerintah sangat diperlukan untuk keberhasilan dalam pengelolaan sampah (Arsanti dan Giyarsih, 2012).

Sampai dengan saat ini, berbagai strategi telah ditempuh oleh pemerintah dan pemangku kepentingan yang lain. Proses penyadaran masyarakat dengan kampanye 3R sudah berlangsung bertahun-tahun di berbagai kota/kabupaten. Berbagai bentuk pengelolaan sampah skala lingkungan juga bermunculan, seperti pengelolaan sampah mandiri, bank sampah, sedekah sampah, TPS 3R, dan sebagainya.

Data Kementerian Lingkungan Hidup dan Kehutanan 2016 menunjukkan bahwa pada tahun 2015 pengurangan sampah hanya sebesar 6,5 juta ton (10\%) dari 71 juta ton sampah yang dihasilkan. Sumber timbulan sampah terbesar berasal dari sampah rumah tangga (48\%), pasar tradisional (24\%), kawasan komersial $(9 \%)$, jalan $(7,5)$, kantor $(6 \%)$, sekolah (4\%), dan lainnya sebesar $1,5 \%$. Upaya atau gerakan 3R juga belum menunjukkan hasil yang signifikan, terbukti hanya 7,02 \% dari sampah yang terolah menjadi kompos, 6,98\% diolah lainnya, sebanyak 66,39\% dari total sampah ditimbun di TPA dan 19,62 \% tidak terkelola (Ditjen PSLB3, 2017). Hal ini menunjukkan bahwa pola pengelolaan sampah konvensional (kumpul-angkut-buang) masih mendominasi pengelolaan sampah di Indonesia.

Hasil monitoring dan evaluasi pengelolaan TPS 3R tahun anggaran 2012 yang diinisiasi oleh Direktorat PLP Cipta Karya menunjukkan keberfungsian TPS 3R masih rendah. Sebanyak $20 \%$ TPS 3R tidak berfungsi, $46 \%$ kurang berfungsi dan hanya $34 \%$ yang dapat berfungsi. Parameter utama yang paling mempengaruhi ketidakberfungsian TPS 3R adalah potensi keberlanjutan program dengan prosentase $0,46 \%$ dan peran serta masyarakat dengan prosentase $2 \%$. Rendahnya potensi keberlanjutan dan peran serta masyarakat terlihat dari disebabkan oleh tidak adanya sumber pendanaan yang memadai untuk keberlangsungan TPS 3R, tidak adanya pendampingan secara berkelanjutan dalam operasional TPS 3R, kurangnya monitoring dari 
Pemda atau Dinas terkait. Pada aspek peran masyarakat disebabkan oleh lemahnya keterlibatan masyarakat dalam kegiatan TPS 3R dan lemahnya komitmen masyarakat untuk membantu dan mengembangan kegiatan di TPS 3R (Direktorat PPLP, 2013).

Dengan berkaca pada permasalahan tersebut, suatu pengkajian mengenai faktor pendorong keberlanjutan pengelolaan sampah rumah tangga berbasis masyarakat diperlukan. Identifikasi faktor pendorong keberlanjutan pengelolaan sampah tersebut sangat penting artinya bagi perumusan kebijakan, strategi dan program / kegiatan pengelolaan sampah partisipatif. Pengkajian mengenai faktor pendorong pengelolaan sampah berbasis partisipasi masyarakat dilakukan pada dua kota, yakni Balikpapan dan Bogor. Kota Balikpapan dipilih karena merupakan kota penerima Adipura Kencana pada tahun 2014 yang pengelolaan sampahnya sudah diakui secara nasional, sementara kota Bogor di pilih karena terdapat contoh terbaik (best practices) pengelolaan TPS 3R yang berfungsi dengan baik dan berkelanjutan. Kota Balikpapan memiliki 558 TPS dimana 82,08 \% telah berfungsi dan dinilai memenuhi syarat, sementara 18,40 $\%$ tidak memenuhi syarat. Angka tersebut menunjukkan bahwa sebagian besar sarana pengelolaan sampah bekerja dengan optimal (DKPP Kota Balikpapan, 2014). Berdasarkan informasi dari Dinas Lingkungan Hidup dan Kehutanan (DLHK) kota Bogor, semenjak dilakukan pilot project di tahun 2005 mengenai kegiatan pengomposan maka semakin tumbuh kegiatan pengomposan sampah diberbagai lokasi secara konsisten seperti di wilayah Perumahan Griya Melati, Indra Prasta, Bantar Kemang, Gunung Batu, Yasmin dan Mulya Harja. Hal ini menunjukkan peningkatan partisipasi masyarakat dalam pengelolaan sampah di kota Bogor. Tulisan ini bertujuan untuk menganalisis faktor-faktor pendorong keberlanjutan pengelolaan sampah partisipatif di kota Bogor dan Balikpapan. Hasil analisis ini diharapkan dapat menjadi bahan untuk penyusunan kebijakan optimalisasi dan keberlanjutan pengelolaan sampah partisipatif, khususnya di kedua wilayah tersebut.

\section{TINJAUAN PUSTAKA}

\subsection{Partisipasi Masyarakat dalam Pengelolaan Sampah}

Menurut Undang-Undang Nomor 18 tahun 2008 tentang Pengelolaan Sampah menyebutkan bahwa masyarakat harus berpartisipasi dalam pengelolaan sampah rumah tangga dan sampah sejenis rumah tangga, dalam hal pengurangan sampah dan penanganan sampah. Sebelumnya, keterlibatan masyarakat dalam mengelola sampah sudah pernah diatur dalam Peraturan Menteri Pekerjaan Umum No. 21/PRT/M/2006 tentang Kebijakan dan Strategi Nasional Pengembangan Sistem Pengelolaan Persampahan. Pengelolaan sampah berbasis masyarakat merupakan salah satu strategi dari kebijakan dalam Peraturan Menteri No. 21/PRT/M/2006 berupa peningkatan peran aktif masyarakat dan dunia usaha/swasta sebagai mitra pengelolaan (Sidiq, 2009).

Pengelolaan Sampah Berbasis Masyarakat (PSBM) atau Community Based Solid Waste Management (CBSWM) adalah sistem penanganan sampah yang direncanakan, disusun, dioperasikan, dikelola dan dimiliki oleh masyarakat. Tujuannya adalah agar tercapai kemandirian masyarakat dalam mempertahankan kebersihan lingkungan melalui pengelolaan sampah yang 
ramah lingkungan. Adapun prinsip-prinsip PSBM terdiri dari partisipasi masyarakat, kemandirian, efisiensi, perlindungan lingkungan serta keterpaduan (Sidiq, 2009).

Keberhasilan pengelolaan sampah di daerah karena semua stakeholder-nya berperan aktif dalam mengelola sampah. Semangat masyarakat didukung penuh oleh pemerintah daerah, seperti melalui pemberian sarana dan prasarana dan dukungan regulasi, disamping dukungan pihak swasta, LSM, media massa, dan perguruan tinggi (Leksono, 2009). Pengelolaan sampah berbasis masyarakat tidak akan berkelanjutan tanpa adanya kemitraan yang kuat antara kelompok masyarakat dan pemerintah daerah. Pemerintah daerah seharusnya menciptakan kerangka kerja bersama yang dapat memberi peluang kerjasama antara penanggung jawab persampahan di pemerintahan daerah dan pemuka kelompok masyarakat (Mungkasa, 2009).

Keberhasilan pengelolaan sampah di lingkungan permukiman masih sangat bergantung pada keberadaan kampiun. Kampiun merupakan istilah bagi tokoh masyarakat yang memiliki komitmen tinggi dalam mengelola sampah di lingkungannya, mempengaruhi masyarakat sekitarnya untuk mengelola sampah bersama-sama. Jika kampiun bisa ditemukan, maka pengelolaan sampah di lingkungan permukiman dapat berjalan lancar. Kampiun sendiri bisa seorang tokoh masyarakat, guru, atau bahkan ibu rumah tangga. Dalam kasus pengolahan sampah, kampiunnya rata-rata merupakan ibu rumah tangga (Mungkasa, 2009 dan Widiarti, 2012).

\subsection{Pendorong Keberlanjutan Pengelolaan Sampah}

Berbagai ahli telah mengemukakan tentang faktor pendorong keberlanjutan pengelolaan sampah berbasis masyarakat. Menurut Klundert dan Anschutz (2001), terdapat 6 aspek pengelolaan sampah terpadu yang berkelanjutan yaitu; teknis, lingkungan, ekonomi/finansial, sosial budaya, institusional/kelembagaan, dan peraturan/kebijakan. Tiga prinsip keberlajutan pengelolaan sampah terpadu meliputi secara ekonomi menguntungkan, secara ekologis dapat dipertanggungjawabkan (ramah lingkungan) dan secara sosial budaya dapat diterima oleh sistem dan tata sosial (Utami et al., 2008).

Penelitian terhadap pengelolaan sampah rumah tangga di kelurahan Tembalang kota Semarang menunjukkan faktor pendorong berupa kesadaran terhadap dampak dan manfaat pengelolaan sampah, manfaat ekonomi penjualan sampah anorganik, manfaat kompos untuk penghijauan lingkungan, kinerja kelompok tani cinta bunga/kelembagaan, pendidikan dan pengalaman serta ketersediaan sarana (Hapsari, 2014). Penelitian lain di Jakarta Selatan menunjukkan peran tokoh agama, tokoh masyarakat dan media massa menjadi elemen kunci dalam mendorong pengelolaan sampah partisipatif melalui peran sosialisasi dan komunikasi efektif kepada warga masyarakat (Kholil et al., 2008). Fenomena menarik di wilayah Banjarsari Jakarta Selatan bahwa kegiatan replant (penghijauan) dapat menambah manfaat ekonomi pengelolaan sampah secara berkelanjutan dengan adanya nilai tambah dari tanaman hias dan tanaman obat keluarga yang di nikmati bersama (Utami et al., 2008). 


\section{METODE PENELITIAN}

Pendekatan yang digunakan pada penelitian ini berupa metode kualitatif. Analisis data dilakukan melalui proses deskripsi, tendensi, dan interpretasi setiap faktor pendorong keberlanjutan pengelolaan sampah. Proses deskripsi adalah upaya untuk menggambarkan persamaan dan perbedaan setiap faktor pendorong pengelolaan sampah rumah tangga di kedua kota. Proses tendensi dilakukan untuk melihat kecenderungan yang menunjukkan derajat kualitas persamaan dan perbedaan faktor pendorong tersebut. Proses interpretasi berupa penjelasan adanya persamaan dan perbedaan serta tendensi yang terlihat di kedua lokasi tersebut (Usman, 2011). Dalam tulisan ini, kualitas dapat dimaknai dari aspek efektifitas pengelolaan sampah berbasis partisipasi masyarakat guna mencapai keberlanjutan pengelolaan sampah tersebut.

Berdasarkan hasil kajian pustaka yang dari Hapsari (2014), Kholil et al. (2008), Utami et al. (2008), maka faktor-faktor pendorong keberlanjutan pengelolaan sampah berbasis partisipasi masyarakat tersebut meliputi peran tokoh masyarakat, manfaat ekonomi, manfaat sosial, manfaat lingkungan. Selain itu penulis menambahkan faktor jaringan antar pelaku serta stimulasi dan fasilitasi pemerintah daerah sebagai faktor pendorong keberlanjutan pengelolaan sampah, sebagai bagian dari aspek institusional/kelembagaan sebagaimana yang disampaikan oleh Klundert dan Anschutz (2001).

Untuk memperoleh data dan informasi yang akurat mengenai faktor-faktor pendorong keberlanjutan tersebut, maka dilakukan beberapa metode pengambilan data dan informasi meliputi wawancara tokoh dan instansi, observasi lapangan, dan dokumentasi data sekunder. Wawancara tokoh dan instansi dilakukan kepada Lurah, pengelola TPS 3R, pengelola bank sampah, tokoh pemuda Karang Taruna, ibu-ibu penggerak PKK, dan pejabat terkait di dinas kebersihan atau dinas lingkungan hidup. Observasi lapangan dilakukan dengan meninjau kegiatan penanganan sampah di lingkungan permukiman, TPS 3R, dan Bank Sampah. Dokumentasi data sekunder dilakukan dengan mempelajari data dan profil penanganan sampah di masing-masing kota. Berikut metode pengumpulan dan analisis data yang telah dilakukan (Tabel 1).

\section{HASIL DAN PEMBAHASAN}

\subsection{Peran Tokoh Masyarakat}

Keberadaan tokoh masyarakat dalam pengelolaan sampah partisipatif berperan penting dalam mempelopori, mengkampanyekan, dan mengelola sampah dilingkungannya. Dalam mempelopori pengelolaan sampah, masyarakat kita masih membutuhkan figur teladan yang dapat dijadikan panutan. Tabel 2 menunjukkan informasi peran masing-masing tokoh di kota Bogor dan Balikpapan.

Tokoh-tokoh masyarakat yang bergerak dalam pengelolaan sampah di kota Bogor merupakan tokoh pemuda, ibu-ibu PKK hingga ketua RT/RW dan lurah. Para tokoh pemuda memandang kebiasaan masyarakat membuang sampah sembarangan ke sungai merugikan masyarakat dan harus dihentikan. Para pemuda tersebut mengambil resiko 
bertentangan dengan masyarakat umum ketika pemerintah berencana memfasilitasi TPS 3R di lingkungan mereka. Dengan kegigihan para pemuda, dampak positif pengelolaan sampah dengan pola 3R terhadap lingkungan dapat dibuktikan. Sebagian anggota masyarakat yang sebelumnya menolak, menjadi terlibat dalam pengelolaan sampah partisipatif.

Peran tokoh perempuan yang bergerak dalam wadah gerakan PKK juga cukup signifikan. Gerakan PKK di kota Bogor menjadi mitra Dinas Kebersihan dan Pertamanan (DKP) kota Bogor dalam mensosialisasikan pengelolaan sampah skala rumah tangga. Mereka bergerak aktif melakukan penerapan TTG pembuatan kompos dengan metode takakura di kelurahan Cilendek Barat, Mekarwangi, Cibuluh dan Cibadak. Gerakan PKK juga dimanfaatkan oleh tokoh pemuda di kelurahan Mulyaharja untuk mensosilasikan pengelolaan sampah 3R di masyarakat. Selain itu, peran tokoh formal seperti ketua RT/RW dan lurah tidak kalah penting. Mereka yang selama ini memfasilitasi masyarakat dalam pemilihan lokasi TPS 3R, mendukung KSM (kelompok keswadayaan masyarakat) pengelola TPS 3R di lingkungan mereka. Tanpa dukungan dan fasilitasi ketua RT/RW dan lurah, keberadaan TPS 3R akan sulit diwujudkan. Dukungan tokoh formal semakin menguatkan kiprah para tokoh informal yang bergerak di lapangan.

Tabel 1. Metode pengumpulan dan analisis data

\begin{tabular}{|c|c|c|}
\hline $\begin{array}{c}\text { Teknik } \\
\text { Pengumpulan Data }\end{array}$ & Sumber Data & Metode Analisis \\
\hline Wawancara & $\begin{array}{l}\text { - Kota Bogor : Tokoh PKK kelurahan } \\
\text { Mulyaharja, Cilendek Barat, Mekarwangi, } \\
\text { Cibuluh dan Cibadak; Lurah Mulyaharja; } \\
\text { Pengurus Asosiasi KPS 3R; Bidang } \\
\text { Pembinaan Pengelolaan Sampah DKP } \\
\text { - Kota Balikpapan : Pengurus Bank Sampah } \\
\text { Tegalsari, Batu Ampar, Graha Indah, } \\
\text { Sepinggan, Damai Bahagia, Damai Baru, } \\
\text { Gunung Bahagia, Gunungsari Ulu, } \\
\text { Sumberejo, Karangrejo, Mekarsari, Muara } \\
\text { Rapak, Prapatan, Lamaru, Klandasan Ulu, } \\
\text { Manggar, Manggar Baru, dan Karang } \\
\text { Joang; Ketua LSM WALIBAR, Seksi } \\
\text { Kebersihan Jalan dan Lingkungan DLH }\end{array}$ & Deskriptif kualitatif \\
\hline Observasi Lapangan & $\begin{array}{l}\text { - TPS 3R Mulyaharja } \\
\text { - Bank Sampah }\end{array}$ & Deskriptif kualitatif \\
\hline $\begin{array}{l}\text { Dokumentasi Data } \\
\text { Sekunder }\end{array}$ & $\begin{array}{l}\text { - Paparan Monitoring dan Evaluasi } \\
\text { Kegiatan 3R } 2013 \\
\text { - Profil Pengelolaan Sampah Kota } \\
\text { Balikpapan } 2014 \\
\text { - Profil Pengelolaan Sampah Kota Bogor } \\
2013\end{array}$ & Deskriptif kualitatif \\
\hline
\end{tabular}


Tabel 2. Peran tokoh masyarakat

\begin{tabular}{|c|c|c|}
\hline $\begin{array}{c}\text { Elemen Tokoh } \\
\text { Masyarakat }\end{array}$ & Bogor & Balikpapan \\
\hline $\begin{array}{l}\text { Tokoh perempuan (PKK } \\
\text { dan Dasa Wisma) }\end{array}$ & 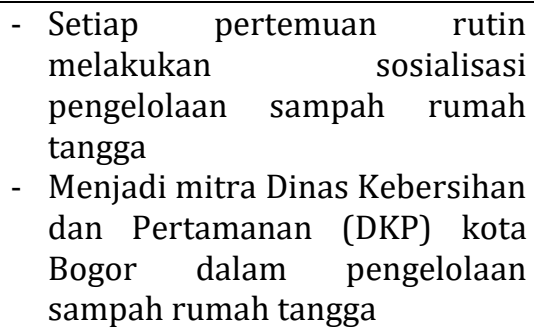 & $\begin{array}{l}\text { - Setiap pertemuan rutin } \\
\text { melakukan sosialisasi } \\
\text { pengelolaan sampah rumah } \\
\text { tangga dengan pola bank } \\
\text { sampah } \\
\text { - Membentuk } \\
\text { menyelenggarakan bank sampah } \\
\text { di berbagai wilayah }\end{array}$ \\
\hline $\begin{array}{l}\text { Tokoh pemuda karang } \\
\text { taruna }\end{array}$ & $\begin{array}{l}\text { - } \text { Mempelopori sosialisasi TPS 3R } \\
\text { di saat sebagian warga menolak } \\
\text { - } \text { Menjadi penggerak dan } \\
\text { pengelola TPS 3R }\end{array}$ & $\begin{array}{l}\text { - Pemuda khususnya pelajar lebih } \\
\text { banyak terlibat di sekolah dalam } \\
\text { program adiwiyata } \\
\text { - Peran di lingkungan tidak terlalu } \\
\text { menonjol }\end{array}$ \\
\hline Ketua RT/RW & $\begin{array}{l}\text { - } \text { Mendukung pengelolaan } \\
\text { sampah melalui TPS 3R } \\
\text { - } \text { Memfasilitasi pertemuan- } \\
\text { pertemuan } \\
\text { - } \\
\text { Memfasilitasi pemilihan lokasi } \\
\text { TPS 3R }\end{array}$ & $\begin{array}{l}\text { - Aktif dalam memfasilitasi } \\
\text { kegiatan bank sampah } \\
\text { - Menyediakan lahan/lokasi bank } \\
\text { sampah } \\
\text { - Memfasilitasi tempat pertemuan } \\
\text { pengelola bank sampah }\end{array}$ \\
\hline Lurah & $\begin{array}{l}\text { - } \text { Mendukung pengelolaan } \\
\text { sampah melalui TPS 3R } \\
\text { - } \text { Memfasilitasi pertemuan- } \\
\text { pertemuan } \\
\text { - } \text { Memfasilitasi pemilihan lokasi } \\
\text { TPS 3R } \\
\text { - } \\
\text { Memberikan akses kepada } \\
\text { dinas/instansi terkait } \\
\end{array}$ & $\begin{array}{l}\text { - Bersama pemkot Balikpapan } \\
\text { memfasilitasi bimbingan teknis } \\
\text { pengelolaan sampah } \\
\text { - Memilih kader-kader lingkungan } \\
\text { untuk dilatih pengelolaan } \\
\text { sampah }\end{array}$ \\
\hline Tokoh LSM Lingkungan & $\begin{array}{lll}\text { - } & \text { Sosialisasi dan kampanye } \\
& \text { pengelolaan sampah } & \\
\text { - } & \text { Pendidikan dan pelatihan } \\
& \text { pengelolaan sampah } & \end{array}$ & $\begin{array}{l}\text { - Sosialisasi pengelolaan sampah } \\
\text { - Pendidikan dan pelatihan } \\
\text { pengelolaan sampah } \\
\text { - Memfasilitasi pembentukkan } \\
\text { bank sampah } \\
\text { - Memfasilitasi pemasaran bank } \\
\text { sampah } \\
\text { - Memfasilitasi akses ke } \\
\text { sumberdaya }\end{array}$ \\
\hline
\end{tabular}

Sumber: Analisis peneliti (2014)

Tokoh atau kader lingkungan sebagian besar merupakan inisiasi masyarakat yang didampingi oleh fasilitasi CSR swasta nasional melalui Yayasan WALIBAR. Oleh karena itu peran LSM tersebut dalam menginisiasi dan mendampingi secara berkelanjutan sangat berarti bagi tumbuh dan berkembangnya kader-kader lingkungan di Balikpapan. Kaderkader lingkungan di Balikpapan mayoritas adalah ibu-ibu dan merupakan pengelola bank sampah di wilayah masing-masing. 
Di wilayah kota Balikpapan, keberadaan bank sampah sangat di dukung oleh tokoh formal seperti ketua RT /RW. Bank Sampah di kota Balikpapan tersebar di berbagai lokasi meliputi bank sampah di kelurahan Tegalsari, Batu Ampar, Graha Indah, Sepinggan, Damai Bahagia, Damai Baru, Gunung Bahagia, Gunungsari Ulu, Sumberejo, Karangrejo, Mekarsari, Muara Rapak, Prapatan, Lamaru, Klandasan Ulu, Manggar, Manggar Baru, dan Karang Joang. Penyebaran bank sampah diberbagai kelurahan tersebut tidak lepas dari kontribusi tokoh LSM lingkungan dari Yayasan WALIBAR. Selama ini Yayasan WALIBAR telah merintis pembentukkan, melatih, dan membina beberapa bank sampah di kota Balikpapan. Yayasan WALIBAR selalu melibatkan tokoh-tokoh masyarakat terutama ibu-ibu Dasawisma, Ketua RT dan RW dalam mengelola dan membina bank sampah.

Tokoh masyarakat di kota Balikpapan melakukan dukungan kepada bank sampah dalam bentuk penyediaan lahan/lokasi bank sampah dan memfasilitasi pertemuan-pertemuan pengurus bank sampah. Selain itu mereka juga aktif menggerakkan warganya untuk menabung sampah di bank sampah yang ada. Hasil wawancara dengan para pengurus bank sampah di kota Balikpapan menunjukkan bahwa peran tokoh masyarakat sangat dibutuhkan dalam keberlanjutan pengelolaan bank sampah.

Beberapa bentuk peran yang diharapkan oleh pengurus tersebut antara lain tokoh yang memberikan contoh atau teladan, tokoh yang aktif memberikan pendidikan kepada warga, tokoh yang mampu memotivasi warga, tokoh yang mampu membawa aspirasi warga kepada pihak lain, serta keterlibatan aparat setempat seperti lurah hingga Ketua RT. Sebagian pengurus bank sampah menilai peran lurah sebagai perwakilan pemerintah kota kurang optimal. Para pengurus bank sampah berharap peran lurah, khususnya dalam berinteraksi dengan pengurus bank sampah, melakukan tinjauan lapangan dan memfasilitasi ke akses sumberdaya bisa semakin ditingkatkan.

Berdasarkan persamaan faktor ketokohan di kedua kota dapat diketahui bahwa peran tokoh perempuan dan tokoh formal seperti RT/RW sangat berperan penting dalam keberlanjutan pengelolaan sampah. Perbedaan mendasar dikedua kota tersebut adalah peran tokoh pemuda dan lurah yang lebih menonjol di kota Bogor. Untuk kota Bogor, peran ketokohan selain inisiatif masyarakat juga ditopang oleh berbagai fasilitasi pemerintah daerah dalam wujud kemitraan. Sementara peran LSM di kota Balikpapan lebih dominan dalam menggerakkan inisiatif masyarakat. Jika dilihat dari perbedaan khususnya pada peran pemuda, keberlanjutan di kota Bogor lebih menjanjikan. Hal ini disebabkan para pemuda yang memiliki kepedulian punya semangat, energi, dan kapasitas yang lebih memiliki daya tahan dalam jangka panjang. Sebaliknya peran LSM yang mampu mendayagunakan program CSR di Balikpapan menjadi keunggulan karena proses akses dan fasilitasi ke sumberdaya menjadi lebih fleksibel dalam menjangkau warga masyarakat. Dengan demikian, kegiatan pengelolaan sampah rumah tangga tidak tergantung pada program pemerintah kota yang dapat terkendala aturan birokrasi. 
Faktor peran tokoh masyarakat merupakan pendorong paling kuat terhadap keberlanjutan pengelolaan sampah berbasis masyarakat. Setelah membandingkan dengan faktor-faktor lainnya, tanpa adanya tokoh masyarakat yang mempelopori, memberikan kesadaran, menggerakkan masyarakat secara konsisten, apapun program dan gerakan pengelolaan sampah tidak akan berjalan dengan optimal. Manfaat ekonomi, sosial, dan lingkungan dari pengelolaan sampah tidak dapat terwujud jika tidak ada yang mau memimpin masyarakat dalam pengelolaan sampah. Selain itu masyarakat di kota Balikpapan secara mandiri bisa mengelola sampahnya melalui bank sampah sehingga tidak terlalu tergantung dengan program dan dukungan pemerintah kota Balikpapan.

\subsection{Manfaat Ekonomi}

Pengelolaan sampah partisipatif di kota Bogor dapat berjalan di masyarakat karena didorong oleh adanya manfaat ekonomi yang secara tidak langsung dirasakan oleh sebagian masyarakat. Sampah anorganik yang dijual ke pengepul sampah sepanjang tahun 2013 berkisar $1335 \mathrm{~m}^{3}$ per bulan. Sebagai ilustrasi, di TPS 3R dari penjualan plastik dapat menghasilkan uang sebesar satu juta rupiah per bulan. Untuk pemrosesan sampah menjadi kompos di seluruh TPS 3R di kota Bogor sepanjang tahun 2013 mencapai 942 m³ $^{3}$ per bulan. Produksi kompos tersebut ada yang bisa dijual kepada petani dan penjual tanaman hias yang berada di wilayah Bogor. Kompos yang diproduksi TPS 3R kelurahan Mulyaharja misalnya dijual kepada pengembang Bogor Nirwana Residence (BNR) untuk pemupukan taman di kompleks perumahan. Penjualan kompos hasil pengolahan sampah memang tidak sebanyak penjualan sampah anorganik kepada pedagang lapak. Pendapatan dari penjualan kompos memang tidak besar jika dibandingkan dengan pendapatan dari iuran warga, namun dengan pendapatan tersebut menjadi tambahan kesejahteraan untuk petugas diluar upah yang mereka terima setiap bulan.

TPS 3R juga memperoleh pendapatan dari iuran pelayanan sampah. Warga masyarakat yang dilayani oleh pengangkutan dan pemrosesan sampahnya di TPS 3R, membayar iuran sampah per bulan kepada kelompok pengelola sampah (KPS). KPS inilah yang menjadi pengelola TPS 3R di masyarakat. Sebagai ilustrasi, KPS 3R Ciparigi yang melayani 530 KK mendapatkan iuran warga sebesar 7 (tujuh) juta per bulan. Sementara KPS 3R Taruna Kompos Mulyaharja bisa mendapatkan 12 (duabelas) juta per bulan dari iuran warga dari sekitar 750 KK. Pendapatan dari iuran sampah ini untuk biaya operasional TPS 3R dan kesejahteraan para pekerjanya.

Sementara untuk masyarakat Balikpapan terdorong untuk berpartisipasi dalam pengelolaan sampah khususnya di bank sampah karena memiliki manfaat ekonomi yang langsung dirasakan. Manfaat tersebut berupa hasil tabungan sampah yang terkonversi menjadi rupiah. Tabungan tersebut berupa sampah anorganik, seperti kertas, plastik, kaca, dan lainnya yang dijual oleh bank sampah ke lapak pengepul sampah. Sistem tabungan 
menggunakan bagi hasil antara nasabah dengan Bank Sampah. Yayasan WALIBAR melaporkan bahwa omzet bank sampah yang didampingi sejumlah 52 unit sudah mencapai 135 juta pada tahun 2012. Manfaat ini sangat dirasakan oleh nasabah untuk menutupi kebutuhan sehari-hari. Hasil tabungan sampah bisa diambil setiap menyetorkan atau akumulasi dalam periode tertentu. Dengan demikian tabungan sampah dapat memberikan penghasilan tambahan yang bermanfaat, sehingga mendorong untuk terus berpartipasi dalam pengelolaan sampah.

Berdasarkan uraian tersebut, manfaat ekonomi yang langsung maupun tidak langsung dirasakan rumah tangga dari proses pengolahan sampah terbukti menjadi pendorong keberlanjutan yang signifikan. Catatan penting yang perlu diperhatikan, di kedua wilayah ini proses daur ulang sampah anorganik belum berkembang baik. Terdapat kecenderungan masyarakat belum mau melakukan daur ulang sampah anorganik menjadi kerajinan misalnya kalau antara biaya, waktu, dan tenaga yang digunakan tidak sebanding dengan pendapatan yang diperolehnya. Apalagi jika di wilayah tersebut tidak ada potensi pasar hasil daur ulang sampah yang pasti dan berkelanjutan.

\subsection{Manfaat Sosial}

Semenjak inisiasi pengelolaan sampah partisipatif di kota Bogor, terdapat beberapa perubahan sosial yang terjadi di masyarakat. Sebelumnya sering terjadi konflik antar tetangga atau antar wilayah yang diakibatkan pembuangan sampah yang sembarangan. Setelah program pengelolaan sampah partisipatif berjalan, konflik antar warga atau wilayah berkurang. Berkurangnya konflik sosial tersebut mendorong masyarakat untuk melanjutkan pengelolaan sampah partisipatif.

Perubahan perilaku membuang sampah secara perlahan terjadi di wilayah-wilayah yang sebelumnya membuang sampah di sungai. Pengamatan lapangan di kelurahan Mulyaharja menunjukkan sungai yang melintas di wilayah desa cukup bersih. Perubahan perilaku tersebut merupakan dampak positif sekaligus pendorong pengelolaan sampah partisipatif. Perubahan perilaku menjadi pendorong karena menstimulasi warga lain untuk melakukan pengelolaan sampah. Sebagai contoh di kelurahan Ciparigi dan Mulyaharja, komplekskompleks perumahan disekitar TPS 3R meminta pelayanan penanganan sampah mereka. Sebagai syarat dari pelayanan penanganan sampah, setiap rumah wajib melakukan pengumpulan sampah pada satu wadah tertentu sehingga sampah tidak berceceran.

Pada wilayah kota Balikpapan, keberhasilan memboyong Adipura Kencana menjadi prestasi sosial yang dibanggakan warga. Secara sosial hal ini bermanfaat menguatkan semangat dan partisipasi warga dalam mengelola sampah. Semakin banyak bank sampah tumbuh karena kesadaran sosial akan mempengaruhi terciptanya kebersihan kota dan mendapatkan penghargaan tersebut. Tumbuhnya bank sampah juga dirasakan mampu menguatkan kohesi sosial dari warga yang berpartisipasi. Secara periodik warga bertemu dan saling berbagi saat menyetorkan sampah ke bank sampah. Manfaat ini penting nilainya 
bagi terciptanya kenyamanan sosial serta konsistensi semangat dalam melakukan pengelolaan sampah.

Manfaat sosial yang di tunjukkan di kedua kota menandaskan bahwa manfaat sosial berupa meningkatnya keharmonisan warga dan prestise wilayah akibat berkembangnya pengelolaan sampah rumah tangga secara tidak langsung berpengaruh kepada keberlanjutan pengelolaan sampah itu sendiri. Kunci keberlanjutan yang esensial secara sosial adalah adanya perubahan perilaku warga dalam penanganan sampah. Perubahan perilaku ini penting bagi keberhasilan pengelolaan sampah partisipatif dan pengembangannya. Perubahan perilaku yang meluas akan berimplikasi positif bagi tumbuhnya unit-unit pengelolaan sampah terpadu yang baru.

\subsection{Manfaat Lingkungan}

Manfaat lingkungan yang dirasakan warga masyarakat merupakan pendorong utama pengelolaan sampah partisipatif di kota Bogor. Wilayah-wilayah yang sebelumnya tidak dilayani sarana pengangkutan dan pemrosesan sampah, menjadi tertangani dengan adanya TPS 3R. Pada saat belum adanya pelayanan TPS 3R, sampah di buang sembarangan dan berserakan di berbagai tempat. Kelurahan Ciparigi dan Mulyaharja dilewati sungai yang menjadi tempat sampah raksasa oleh sebagian warga yang tidak bertanggungjawab.

Dengan adanya TPS 3R secara perlahan kebiasaan membuang sampah ke sungai berubah. Dengan pelayanan pengangkutan sampah oleh KPS 3R, warga yang tadinya membuang sampah ke sungai beralih mengumpulkan sampahnya didepan rumah untuk diangkut oleh motor sampah. Berdasarkan pengamatan lapangan di Mulyaharja, sekitar jam 10 pagi proses pengangkutan sampah sudah selesai dilakukan. Dengan kondisi tersebut, wilayah permukiman terlihat bersih dari sampah. Sungai yang melewati permukiman penduduk juga terlihat bersih.

Secara keseluruhan, manfaat lingkungan dari pengelolaan sampah partisipatif telah mampu mereduksi sampah di kawasan permukiman. Data DKP kota Bogor menyebutkan pada tahun 2013 pengelolaan sampah dengan TPS 3R mereduksi sampah $94 \mathrm{~m}^{3}$ per hari atau 3,78 \% dari total timbulan sampah kota. Angka ini memang masih kecil pada skala kota, namun mampu menstimulasi partisipasi masyarakat pada tingkat lokal.

Pengelolaan sampah partisipatif pada dasarnya guna mengurangi beban TPA dan meminimalisasi dampak lingkungan akibat menumpuknya sampah di mana-mana. Kesadaran pengelolaan sampah di Balikpapan mulai tumbuh sejak era 1990-an. Hal ini sejalan dengan pertumbuhan pesat fisik dan penduduk kota yang berimplikasi bagi meningkatnya timbulan sampah.

Manfaat lingkungan semakin terasa seiring dengan keberhasilan mewujudkan kota yang bersih. Kebersihan nampak di beberapa sudut dan sungai. Keberhasilan ini semakin dirasakan warga setelah sukses mendapatkan penghargaan Adipura Kencana pada tahun 2013. Prestasi ini semakin menguatkan kesadaran warga bahwa mengelola sampah 
merupakan kunci menciptakan kebersihan kota. Hal ini menjadi bagian pendorong masyarakat terus berpartisipasi dalam pengelolaan sampah. Manfaat lingkungan yang dirasakan antara lain; lingkungan menjadi bersih, mengurangi volume sampah di TPS, dapat dijadikan kompos yang menyuburkan tanaman dan lahan, tidak menimbulkan bau, dan mengurangi resiko penyakit.

\subsection{Stimulasi dan Fasilitasi Pemerintah}

Fasilitasi merupakan salah satu bentuk intervensi pemberdayaan untuk mendorong perubahan di masyarakat secara berkesinambungan dengan mengoptimalkan potensi dan sumberdaya masyarakat. Fasilitasi pemerintah lebih bersifat stimulasi, sehingga setiap fasilitasi dibarengi dengan peran aktif masyarakat. Peran aktif masyarakat inilah yang diharapkan memberikan kontribusi signifikan dalam mengatasi permasalahan sampah.

Pemerintah kota Bogor melakukan berbagai bentuk fasilitasi dalam pengelolaan sampah partisipatif. Adapun bentuk-bentuk fasilitasi pemerintah kota Bogor adalah sebagai berikut. Pertama, melakukan pelatihan pengelolaan sampah rumah tangga dan sejenisnya kepada calon pengelola TPS 3R dalam wadah KPS 3R. Pelatihan yang dilakukan bertujuan meningkatkan pengetahuan dan kapasitas masyarakat dalam mengelola sampah sejak dari sumbernya secara benar. Dari hasil pelatihan inilah bermunculan potensi tokoh-tokoh masyarakat yang menjadi kader lingkungan di wilayahnya.

Kedua, memfasilitasi pembentukkan KPS 3R yang berfungsi sebagai pengelola TPS 3R disetiap wilayah. Pembentukkan KPS 3R dilakukan secara partisipatif dengan dukungan aparat kelurahan setempat. KPS 3R inilah yang menjadi tulang punggung pengelolaman sampah dimasyarakat. Tugas KPS 3R antara lain melakukan sosialisasi/kampanye pengelolaan sampah, mengangkut sampah, melakukan pemrosessan sampah di TPS 3R, memasarkan hasil pengolahan sampah, menarik iuran warga, serta melakukan perawatan dan pemeliharaan sarana dan prasarana TPS 3R.

Ketiga, pemerintah kota Bogor berkomitmen mendampingi TPS 3R yang telah dibangun dengan memberikan beberapa insentif. Kepada tenaga pemilah dan pengolah sampah diberikan insentif upah. Pada tahun 2012 besaran insentif upah yang diberikan sebanyak Rp. 29.040.000,-. Jumlah ini meningkat 4 (empat) kalinya menjadi Rp. 143.100.000,- di tahun 2013. Insentif lain berupa bantuan bahan bakar minyak (BBM) solar senilai Rp. 83.160.000,- dan pertamax sebesar Rp. 65.700.000,- ditahun 2013.

Kelima, melakukan sosialisasi dan pembinaan pengelolaan sampah rumah tangga bekerjasama dengan PKK kota Bogor. Upaya ini dilakukan secara kontinyu dibeberapa kelurahan. Untuk pengolahan sampah menggunakan metode keranjang takakura dan bantuan tong sampah terpilah. Untuk meningkatkan keberlanjutan upaya sosialisasi dan pembinaan, dalam struktur organisasi DKP terdapat bidang pembinaan dan pengelolaan sampah sejak tahun 2011. Dengan penguatan kelembagaan ini, program dan kegiatan pengelolaan sampah partisipatif lebih mendapatkan dukungan pemerintah. 
Di Balikpapan, pengelolaan sampah partisipatif tumbuh dan berkembang diawali oleh sosialisasi dan bimbingan kepada masyarakat. Sosialisasi dilakukan oleh pemkot maupun LSM. Pemkot Balikpapan sendiri memiliki program peningkatan kapasitas masyarakat dalam pengelolaan sampah, antara lain:

1. Sosialisasi kebijakan pengelolaan persampahan

2. Bimbingan teknis persampahan yang pesertanya dari RT, Kelurahan, Kecamatan, PKK, kader kesehatan dan organisasi masyarakat.

3. Sosialisasi kebijakan dan peningkatan peran serta masyarakat dalam pengelolaan persampahan di tempat-tempat publik dan melalui kegiatan kampanye seperti fotografi, melukis, mewarnai, dan lain - lain.

4. Monitoring dan evaluasi pelaksanaan layanan.

Fasilitasi juga dilakukan dengan pembentukan bank sampah dan TPS 3R. Bank sampah banyak diinisasi oleh warga atas pendampingan WALIBAR. TPS 3R diprakarsai oleh pemerintah. Bank sampah yang tumbuh juga difasilitasi oleh pemerintah di bawah, seperti dengan pemanfaatan tempat milik pemerintah. Tempat bank sampah misalnya bisa memanfaatkan gedung RT. Kompetisi atau perlombaan kebersihan menjadi penting merangsang partisipasi warga. Kompetisi yang ada misalnya Adipura, Balikpapan Green and Clean, Adiwiyata, dan lainnya. Motivasi berlomba menjadi awal menumbuhkan kesadaran pengelolaam sampah. Keberlanjutan selanjutnya dikuatkan dengan bimbingan teknis pengembangan. Hal ini untuk mengantisipasi matinya unit pengelolaan sampah pascakompetisi atau jika kalah kompetisi.

Pemkot Balikpapan memiliki strategi khusus yang berhasil menumbuhkan kesadaran dan kedisiplinan dalam pengelolaan sampah. Salah satunya dengan mengatur waktu pengangkutan sampah dari sumber sampah seperti rumah tangga, warung/toko, dan sebagainya ke TPS yaitu antara pukul 6 Pagi hingga 6 sore. Pengangkutan sampah ke TPS diluar ketentuan tersebut dilarang dan didenda. Operasi Yustisi persampahan dilakukan 34 kali dalam setahun. Dengan penegakkan aturan tersebut, warga kota Balikpapan tumbuh menjadi masyarakat yang disiplin menjaga kebersihan lingkungannya.

\subsection{Jaringan Pengelolaan Sampah}

Faktor pendorong lainnya adalah jaringan pengelolaan sampah. Jaringan pengelolaan sampah merupakan jejaring kerja yang terbangun diantara pelaku pengelolaan sampah baik pada aspek produksi dan pelayanan sampah maupun pemasaran hasil pengolahan sampah. Berdasarkan wawancara dengan DKP Kota Bogor dan pengurus TPS 3R, jaringan pengelolaan sampah yang terbangun di kota Bogor antara lain, asosiasi KPS 3R, jaringan pedagang lapak, dan jaringan dengan petani dan penjual tanaman hias.

Asosiasi atau perkumpulan KPS 3R merupakan wadah komunikasi dan koordinasi para pengelola TPS 3R di kota Bogor. Setiap bulan selalu ada pertemuan di DKP untuk 
menyampaikan laporan pengelolaan TPS 3R dan kendala yang dihadapi di lapangan. Dengan adanya pertemuan ini, menjadi bahan pembelajaran bersama untuk menyelesaikan permasalahan bersama. Sebagai contoh apabila ada produk kompos yang menumpuk dan belum terjual di salah satu TPS 3R, maka anggota KPS 3R yang lain akan membantu menjualkan kompos tersebut.

Jaringan kerja lain yang signifikan perannya adalah pengepul sampah. Pengepul sampah berperan membeli sampah anorganik yang layak jual dari TPS 3R dan bank sampah di masyarakat. Secara umum para pengepul sampah biasanya mendatangi TPS 3R dan melakukan transaksi. Hubungan yang terbangun dalam waktu lama dapat meningkatkan kepercayaan. Dari para pedagang lapak inilah informasi harga sampah terus dapat dipantau.

Jaringan kerja dengan petani dan penjual tanaman hias dibangun untuk penjualan kompos. Wilayah Bogor dan sekitarnya merupakan salah satu sentra produksi anggrek dan pengembangan tanaman hias non anggrek di Indonesia. Dengan kondisi tersebut, produk kompos memiliki pangsa pasar yang cukup besar. Untuk itulah, kerjasama antara pengelola TPS 3R dengan petani dan penjual tanaman hias terus dibangun untuk mendorong keberlanjutan pengelolaan sampah.

Di Kota Balikpapan, pengelolaan sampah partisipatif terdorong karena terciptanya jaringan pengelolaan yang mapan. Jaringan yang selama ini terbentuk antaralain antara bank sampah dengan lapak pengepul serta antara Yayasan Walibar dan bank sampah dengan PT Unilever. Jaringan dengan lapak pengepul penting guna memastikan penjualan tabungan sampah. Jaringan dengan PT. Unilever penting terkait CSR dalam pelaksanaan Balikpapan Green and Clean setiap tahunnya.

Informasi jaringan yang dapat membantu pengelolaan sampah antara lain tentang lapak/pengepul sampah, harga sampah layak jual, harga kompos, dan model kreasi daur ulang. Sebagian besar pengurus bank sampah lebih membutuhkan informasi lapak dan harga sampah layak jual dibandingkan yang lainnya. Hal ini wajar karena bentuk pengelolaan yang berkembang adalah bank sampah. Sementara untuk pengomposan dan kreasi daur ulang sampah belum berkembang sehingga informasi harga kompos dan kreasi daur ulang tidak terlalu dibutuhkan. Aspek lain yang dibutuhkan dalam jaringan pengelolaan adalah berbagai jenis promosi produk daur ulang sampah baik melalui pameran, showroom, agenda wisata, dan edukasi lingkungan lainnya. Dengan promosi ini diharapkan akan membuka pasar produk daur ulang sampah dan mendorong pengelola bank sampah mengembangkan berbagai produk daur ulang sampah.

Faktor jaringan antar pelaku pengelolaan sampah memang belum banyak dibahas di berbagai literatur. Setelah membandingkan dengan berbagai faktor yang lain, faktor jaringan antar pelaku pengelolaan sampah menjadi faktor pendorong kedua yang paling kuat terhadap keberlanjutan pengelolaan sampah partisipatif. Keberadaan jaringan antar pelaku menjadi bukti nyata bahwa hubungan saling menguntungkan antar pelaku 
pengelolaan sampah mampu mendorong keberlanjutan pengelolaan sampah. Selama ini, pengalaman di berbagai wilayah pemasaran hasil daur ulang sampah yang tidak optimal pada akhirnya menjadi penghambat pengelolaan sampah rumah tangga. Dengan demikian, jaringan pengelolaan menjadi salah satu temuan signifikan dalam mendorong keberlanjutan pengelolaan sampah rumah tangga.

\subsection{Rekomendasi pengelolaan sampah partisipatif masyarakat}

Keberhasilan pengelolaan sampah berbasis partisipasi masyarakat dipengaruhi oleh beberapa faktor, dimana untuk peningkatan pengelolaan sampah partisipatif di Kota Bogor dan Balikpapan tersebut, maka direkomendasikan beberapa hal sebagai berikut:

a) Peningkatan kemitraan antara pemerintah kota dengan tokoh informal yang memiliki komitmen dalam pengelolaan sampah partisipatif. Pemberian berbagai apresiasi kepada tokoh masyarakat seperti bantuan keselamatan dan kesehatan kerja, beasiswa untuk anak pengurus kelompok pengelola sampah, menjadi duta pengelolaan sampah dan sebagai nara sumber penyusunan peraturan terkait pengelolaan sampah.

b) Untuk meningkatkan manfaat ekonomi, perlu pendampingan dalam peningkatan wilayah pelayanan dan pemasaran hasil pengolahan sampah. Database tentang harga sampah anorganik, kompos, jaringan pedagang lapak yang up to date sangat bermanfaat bagi kelompok pengelola sampah. Komitmen Pemda untuk membeli kompos dan produk daur ulang sampah bagi program/kegiatan dilingkungan pemerintah kota memberikan kepastian pada produksi dan daur ulang sampah.

c) Mendayagunakan informasi manfaat lingkungan dan ekonomi untuk bahan sosialisasi, kampanye, pelatihan/pendidikan di lingkungan permukiman yang belum melakukan pengelolaan sampah partisipatif.

\section{KESIMPULAN}

Berdasarkan pembahasan faktor-faktor pendorong pengelolaan sampah partisipatif tersebut, maka dapat dikembangkan beberapa kesimpulan sebagai berikut:

1. Faktor pendorong keberlanjutan pengelolaan sampah di kota Bogor dan Balikpapan yang paling kuat adalah peran tokoh masyarakat dan jaringan pengelolaan sampah.

2. Manfaat sosial berupa penghargaan Adipura Kencana menguatkan semangat dan partisipasi warga dalam mengelola sampah sementara di kota Bogor lebih di dorong oleh manfaat lingkungan dengan semakin meningkatnya kebersihan kawasan permukiman.

3. Stimulasi dan fasilitasi dari pemerintah daerah bermanfaat dalam pengelolaan sampah berbasis partisipasi masyarakat di kedua kota, namun tidak terlalu signifikan mendorong keberlanjutan pengelolaan sampah khususnya di kota Balikpapan. 


\section{DAFTAR PUSTAKA}

Arsanti, V., dan Giyarsih, S.R., (2012), Pengelolaan Sampah oleh Masyarakat Perkotaan di Kota Yogyakarta, Jurnal Sains\&Teknologi Lingkungan, 4 (1), pp. 55-66.

Direktorat PPLP., (2012), Pedoman Umum Penyelenggaraan TPS 3R Berbasis Masyarakat, Kementerian Pekerjaan Umum.

Direktorat PPLP., (2013), Paparan Monitoring dan Evaluasi Kegiatan 3R, Kementerian Pekerjaan Umum.

Ditjen PSLB3., (2017), Paparan Sistem Informasi Pengelolaan Sampah Nasional, Kementerian Lingkungan Hidup dan Kehutanan.

DKPP Kota Balikpapan, (2014), Profil Pengelolaan Sampah Kota Balikpapan 2014 Kota Balikpapan: Dinas Kebersihan, Pertamanan, dan Pemakaman.

Hapsari, N., (2014), Evaluasi Program Pengelolaan Sampah Berskala Keluarga di Kelurahan Tembalang, Jurnal Teknik PWK, 3(1), pp. 155-166.

Kholil, Eriyatno, Sutjahyo, S.H., Soekarto, S.H., (2008), Pengembangan Model Kelembagaan Pengelola Sampah Kota dengan Metode ISM (Interpretative Structural Modelling): Studi Kasus di Jakarta Selatan, Jurnal Transdisiplin Sosiologi, Komunikasi, dan Ekologi Manusia, 02(01), pp. 31-48.

Klundert, V.D., and Anshutz, J., (2001)., Integrated Sustainable Waste Management - the Concept. Tools for Decision Maker. Experiences from the Urban Waste Expertise Programme (1995-2001).

Leksono, B., (2009), Tindak Lanjut Undang-Undang Persampahan. Majalah Percik Edisi Mei.

Mungkasa, O., (2009), Pemberdayaan Masyarakat dalam Pengelolaan Sampah. Majalah Percik Edisi Mei.

Sidiq, S., (2009), Implementasi Peran Masyarakat Sesuai UU No. 18 Tahun 2008. Majalah Percik Edisi Mei.

Usman, S., (2011), Level Analisis Penelitian, PIPM Sekolah Pasca Sarjana UGM, pp. 6-8.

Utami, B.D., Indrasti, N.S., Dharmawan, A.H., (2008), Pengelolaan Sampah Rumah Tangga Berbasis Komunitas: Teladan Dari Dua Komunitas di Sleman dan Jakarta Selatan, Jurnal Transdisiplin Sosiologi, Komunikasi, dan Ekologi Manusia, 02(01), pp. 49-68.

UU No. 18 Tahun 2008 tentang Pengelolaan Sampah

Widiarti, I.W., (2012), Pengelolaan Sampah Berbasis “Zero Waste” Skala Rumah Tangga Secara Mandiri, Jurnal Sains\&Teknologi Lingkungan, 4(2), pp. 101-113. 